\title{
Design idea on planning skill training system of real estate development projects in colleges and universities
}

\author{
Kecheng Li, Yuhang Li \& Jian Gou \\ Chongqing Jianzhu College, Chongqing, China
}

\begin{abstract}
The planning skill training of the real estate development project in colleges and universities is an important means for the students majored with the real estate operation and valuation to master it. According to the in-depth researches of the real estate developers and many years' teaching experience, we put forward the design idea of the skill training system. This idea contains three steps: design of training content, design of training mode and design of training system. This idea is helpful for building a sound training system, and is also helpful for the students to effectively carry out skill training, successfully achieve the goal of mastering the vocational skills, and increase the competitiveness of employment after graduation, thus playing a very good reference role in the development of other vocational skill training systems in colleges and universities.
\end{abstract}

Keywords:information technology; colleges and universities; planning of the real estate development projects; skill training; application

\section{INTRODUCTION}

The national laws and government rules regulate that, the land use right of the industry (excluding mining), warehousing, commerce, tourism, entertainment and commercial residential buildings and other commercial construction lands should be publicly transferred in a way of bidding, auction and listing ${ }^{[1][2]}$. Prior to publicly transferring the land use right of the commercial construction lands (hereinafter referred to as the land use right), the land administration authorities of the People's Governments above the county level (hereinafter referred to as the land administration authorities) will also issue the public transfer announcement in the transfer transaction place of the land use right, media and official website, so that the potential transferee of the land use right can be informed timely. After the real estate developers being aware of the public transfer announcement of the land use right, if there is an intention to transfer the land use right for the real estate development, the real estate development projects are planned in accordance with the land conditions and planning indicators publicized, in order to predict the potentially acquired real estate development profits, determine the highest quotation in competition of the land use right, and accordingly decide whether to participate in the public transfer transaction of the land use right.

In the course system of the real estate operation and valuation major in colleges and universities, there is a real estate development and management course. One of teaching objectives of this course is to cultivate the students' theory and ability of being competent in planning of the real estate development projects as the real estate developers. In the process of teaching this course, the classroom teaching methods are commonly used to impart the planning theory of the real estate development projects to the students, and the skill training mode is used to cultivate the students' ability of being competent in planning of the real estate development projects.

Now, the information technology is widely used in all aspects of society. The colleges and universities can use the sophisticated information technology to build a planning skill training system of the real estate development projects, in order to train students and improve the quality and efficiency of training.

To smoothly and orderly conduct the planning skill training of the real estate development projects, and achieve the teaching objectives of the real estate development and management courses, it is necessary to meticulously design the planning skill training of the real estate development projects. Based on the 
well-designed training, the students can effectively master the planning skills of the real estate development projects after training, and increase the competitiveness of employment after graduation.

According to the in-depth researches of the real estate developers and many years' teaching experience, we believe that we should conduct a comprehensive design of planning skill training of the real estate development projects by the use of the information technology in accordance with the ideas of the design of training content, design of training mode and design of training system.

\section{DESIGN OF TRAINING CONTENT}

The planning skill training of the real estate development projects should realistically simulate the whole process as the real estate developers, which is from informing of the government announcement of transferring the land use right to deciding whether to participate in transfer transaction of the land use right.

The information in the public transfer announcement of the land use right issued by the land administration authorities is listed in Table 1.

The relevant information excerpted in the public transfer announcement of the land use right issued by the land administration authority is listed in Table 2.

Any real estate developers will pay close attention to the media and the official website of the land administration authority, and timely inform of the public transfer announcement of the land use right. If the real estate developers have an intention to transfer the land use right for the real estate development, they will immediately follow the information in the announcement to quickly complete the planning of the real estate development projects before the deadline for submission of trading application, and predict the highest quotation in the public transfer transaction, and accordingly decide whether to participate in the public transfer transaction. If deciding to participate in the public transfer transaction of the land use right, they must submit an application to participate in trading and deliver the trading deposit before the deadline of application, and must be cautious in making quotation in the process of trading, and strive to acquire the land use right without exceeding the expected highest quotation.

After the in-depth investigation of the real estate developers, the planning process and content of the real estate development projects are summarized as follows:

(1) To inform of the transfer announcement of the land use right, survey land, and understand the location and surrounding environment of the land.

(2) To develop the real estate development program according to the planning indicators publicized and needs of the local real estate market.

(3) To estimate the real estate development costs, including:

A. To estimate the construction cost of the real estate development projects according to the real estate development program and the cost of the local construction materials, construction equipment and construction labor.

B. To estimate the cost of exploration, design, supervision, cost consulting and other professional services in the real estate development projects according to program.

C. To estimate the administration cost of the real estate development projects according to the program.

D. To determine the promotion means of the real estate, and estimate the selling expense of the real estate development projects.

E. To determine the way to raise the real estate development funds and fund raising cost, and estimate the cost of raising the development funds.

Table 1. Information category and information content of the public transfer announcement of the land use right issued by the land administration authorities

\begin{tabular}{|l|l|l|}
\hline No. & Information category & Information content \\
\hline 1 & Land status information & Area, location, status, purpose, planning restriction indicators and so on \\
\hline 2 & Trade information of the use right & $\begin{array}{l}\text { Trading manner of public transfer, trading location, deadline for submission of trading } \\
\text { application, trading hours, starting price of trading, trading deposit and so on }\end{array}$ \\
\hline
\end{tabular}

Table2. Information excerpt in the public transfer announcement of the land use right issued by the land administration authority

\begin{tabular}{|l|l|l|l|l|l|l|}
\hline \multirow{2}{*}{ Land No. } & Land location & Land purpose & Land area & \multicolumn{3}{|l|}{ Planning indicators } \\
\cline { 3 - 6 } & & & Plot ratio & Building area & Building density & Greening rate \\
\hline FD2013-100-3 & Xinglong Avenue & $\begin{array}{l}\text { Residence, } \\
\text { commerce }\end{array}$ & $43877 \mathrm{~m}^{2}$ & $\leq 3$ & $\leq 131631 \mathrm{~m}^{2}$ & $\leq 40 \%$ \\
\hline Land status & Announcement deadline & $\geq 30 \%$ \\
\hline $\begin{array}{l}\text { Road, water supply, drainage, electricity, } \\
\text { telecommunication accessibility }\end{array}$ & $9: 00$ on August 18, 2013 to 15:00 on August 28, 2013 \\
\hline Starting price of trading & Trading deposit & $\begin{array}{l}\text { Deadline for submission of trading } \\
\text { application }\end{array}$ & $\begin{array}{l}\text { Location of submission of trading } \\
\text { application and trading }\end{array}$ \\
\hline RMB 68,100,000 & RMB 20,000,000 & $15: 00$ on August 28, 2013 & Public Resource Exchange Center \\
\hline
\end{tabular}


Development $\cos \mathrm{t}=$ Construction $\cos \mathrm{C}+$ Cost of professional services + Administration cost + Selling expense + Fund raising cost.

(4) To estimate the sales revenue of the real estate development projects according to the condition of the local real estate market.

(5) To estimate the business tax, land value increment tax, corporate income tax and other taxes payable according to the local tax policy.

(6) To determine the reasonable expected real estate development profits according to the operating conditions of the real estate developers.

(7) To estimate the land cost, land cost $=$ sales revenue-development cost - various taxes - expected profits.

(8) To determine whether the estimated land cost is greater than the starting price of trading publicized. If the estimated land cost is less than the starting price of trading publicized, there is a need to develop the real estate development program again, and then carry out the above-mentioned estimation process again.

If repeatedly estimated land cost is less than the starting price of trading, there is no need to participate in the public transfer transaction of the land use right and there is a need to finish the planning of the real estate development projects. If the estimated land cost is greater than the starting price of trading, there is a need to proceed to the subsequent checking calculation.

(9) To tentatively determine the highest cost of the land according to the estimated sales revenue, development cost, development tax and expected profits determined.

(10) To re-estimate the development tax based on the highest cost of the land tentatively determined and estimated sales revenue and development cost.

(11) To estimate the real estate development profits, namely the real estate development profits = sales revenue - highest cost of the land tentatively determined - development cost - various taxes.

(12) To analyze the degree of impact of changes of the sales revenue, development cost and development tax of the real estate on the development profits of the real estate under the negative impact of the risk factors.

(13) To determine whether the development profits of the real estate are greater than the expected profits under the negative impact of the risk factors. If the development profits of the real estate are less than the expected profits under the negative impact of the risk factors, there is a need to revise determine the highest cost of the land, and re-estimate the development tax, and also carry out risk analysis of the sales revenue, development cost and various taxes of the real estate. After repeated estimation, if the development profits of the real estate are less than the expected profits, there is no need to participate in the public transfer transaction of the land use right and there is a need to finish the planning of the real estate development projects.

(14) If the estimated development profits of the real estate are equal to or greater than the expected profits under the negative impact of the risk factors, the highest cost of the land tentatively determined is the highest quotation in the transaction of the land use right. That is to say, to obtain the land use right based on the quotation of the highest cost of the land, even under the negative impact of the expected risk factors, the developers are still able to obtain the expected development profits. Therefore, the decision can be made to participate in the public transfer transaction of the land use right and finish the planning of the real estate development projects.

Figure 1 shows the entire content and whole process of planning the real estate development projects by the real estate developers. Obviously, the planning skill training of the real estate development projects in colleges and universities must contain the entire content of the planning of the real estate development projects, so that the students majored with the real estate operation and valuation can be trained to master the corresponding skills.

\section{DESIGN OF TRAINING MODE}

According to the cognitive ability and learning ability of the students majored with the real estate operation and valuation in colleges and universities, it is necessary to divide the planning skill training of the real estate development projects into primary, intermediate and advanced level. The training objectives, training content and training difficulty of these three levels are different. After completion of the training of three levels, the planning skill competition of the real estate development projects can also be held to increase the interest of training and enhance the students' initiative to make efforts to complete training.

\subsection{Primary training}

The objective of the primary training is to let the students understand the planning content and process of the real estate development projects, and understand the operation method of the planning skill training system of the real estate development projects, thus laying a good foundation for the intermediate training. The time of primary training is 16 hours. Before the primary training, the teachers prepare a written Guide Book of Primary Training of Planning Skills of Real Estate Development Projects, which contains:

(1) Description and detailed operation method of the planning simulation training system of the real estate development projects.

(2) Complete public transfer announcement of the land use right. 


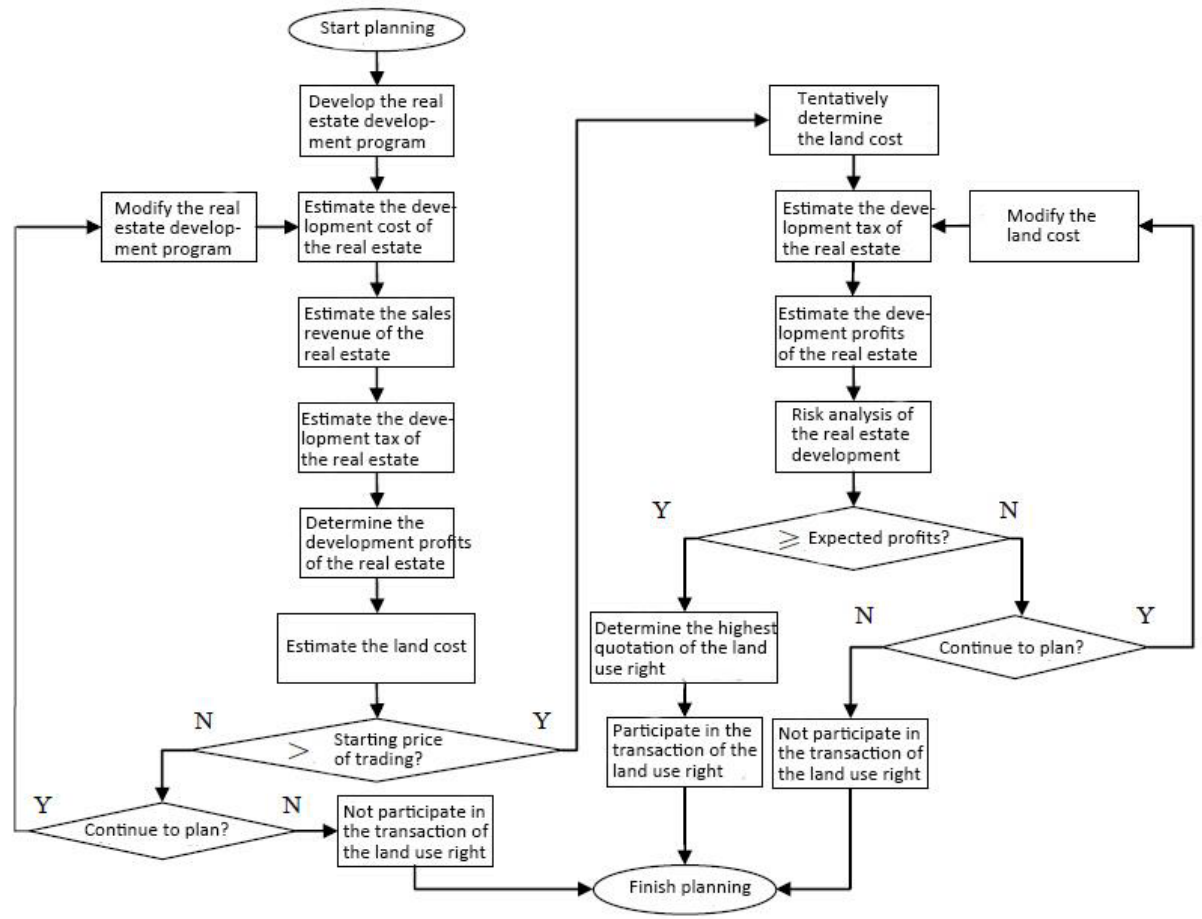

Figure 1. Content and process of planning real estate development projects by the real estate developers

(3) Complete program of the real estate development projects.

(4) Basic data of the estimated real estate development cost, development income and development tax, and expected profits. The expected profit is expressed by the profit rate of development income. Before 24 hours of primary training, the teachers distribute the written Guide Book of Primary Training of Planning Skills of Real Estate Development Projects to the training students for advance preparation, and as a basis for the completion of primary training.

Primary training is carried out in accordance with the following steps:

(1) The teachers are guided to explain the operation method of the planning skill training system of the real estate development projects to the students in detail.

(2) The students carry out the experimental operation after finishing the explanation.

(3) The students complete the content of primary training in accordance with the program of the real estate development projects and various basic data provided in the Guide Book of Primary Training of Planning Skills of Real Estate Development Projects. After the primary training, the teachers evaluate the performance of the primary training of the students and then shift to the intermediate training according to the time used by the students to complete the primary training.

\subsection{Intermediate training}

The objective of the intermediate training is to let the students familiarize with the planning content and process of the real estate development projects, and familiarize with the operation method of planning skill training system of the real estate development projects, thus laying a good foundation for the advanced training. The time of intermediate training is 24 hours. Before the intermediate training, the teachers prepare the following documents to release in the planning skill training system of the real estate development projects:

(1) Complete public transfer announcement of the land use right.

(2) Basic data of the estimated sales revenue of the real estate development projects, various costs, various expenses and various taxes, and expected profits. The expected profit is expressed by the profit rate of the sales revenue.

(3) Basic data of risk analysis of the sales revenue, various costs, various expenses and various taxes. The students visit the server on the terminal computer to browse the public transfer announcement, and analyze the basic data and develop the program of the real estate development projects according to the land conditions and planning indicators publicized, and complete the content of intermediate training based on the basic data.

Differences between intermediate training and primary training:

(1) To release the public transfer announcement of the land use right, and basic data required by the estimation and risk analysis in the skill training system, rather than distribution of the written guide book of skill training to the students. The students visit the server on the terminal computer to browse the public transfer announcement and various basic data, in order 
to simulate the real estate developers to acquire the public transfer announcement of the land use right from the official website of the land administration authorities.

(2) The students independently prepare the program of the real estate development projects according to the land conditions and planning indicators publicized, rather than providing any programs of the real estate development projects to the students.

(3) To increase the training content of the risk analysis of sales revenue, various costs, various expenses and various taxes.

(4) The students complete the content of intermediate training according to the program of the real estate development projects independently developed by the students and various basic data provided by the teachers.

After completing the intermediate training by all training students, the teachers organize the simulation auction of the land use right, and the training students submit the quotation from their respective terminal computers. After several rounds of quotation, the students with the land use right can be competed based on the success of highest-price-offer. The teachers evaluate the performance of the intermediate training of the students and then shift into the advanced training according to the degree of the highest quotation determined by the students.

\subsection{Advanced training}

The objective of the advanced training is to let the students grasp the planning content and process of the real estate development projects, and grasp the operation skills of the planning skill training system of the real estate development projects, and strengthen the planning skills of the real estate development projects. The time of advanced training is 32 hours.

Before the advanced training, the teachers only release the public transfer announcement of the land use right in the planning skill training system of the real estate development projects, without further releasing any basic data required by planning. The students visit the server on the terminal computer to browse the announcement, and login the relevant websites on Internet to retrieve and collect the basic data required by planning, and independently develop the program of the real estate development projects according to the land conditions and planning indicators publicized, and complete the content of advanced training based on the basic data retrieved and collected.

In the process of advanced training, the students retrieve and collect the basic data required by planning, who can login the following websites on the Internet: (1) official website of the government administrative authority, (2) website of the real estate development industry and real estate developer, (3) website of the real estate brokerage industry and real estate brokerage agency, (4) website of the real estate appraisal industry and real estate appraisal agency, (5) website of the construction industry and construction enterprise, (6) website of the construction materials industry and construction materials manufacturer and supplier, (7) website of the construction equipment industry and construction equipment manufacturer and supplier, (8) website of the employment agency.

Under permissible conditions, the teachers should also encourage and actively guide the students to collect the basic data required by planning at the sales site of the real estate development projects, construction site of the real estate development projects, construction materials market and construction equipment markets through the market research.

The difference between the advanced training and intermediate training lies in, the students independently retrieve or collect the basic data required by planning through the Internet or market research, rather than providing the students with any basic data required by planning.

The advanced training realistically simulates the whole process of planning the real estate development projects by the real estate developers, which is fruitful for training the students' planning ability of the real estate development projects.

After completion of the advanced training for all students, the teachers organize to simulate the auction of the land use right, and the training students respectively submit the quotation from the terminal computer. After several rounds of quotation, the students with the land use right can be competed based on the success of highest-price-offer. The teachers comprehensively evaluate the performance of the advanced training of the students according to the highest quotation determined by the students and the level of the estimated real estate development profits.

\subsection{Planning skill competition of the real estate de- velopment projects}

The objective of the planning skill competition of the real estate development projects is to test the students' training effect, and the competition is fully carried out in accordance with the manner and difficulty of the intermediate training. The competition time is not more than four hours. Therefore, the land area publicized in the public transfer announcement of the land use right should not be too large, in order to avoid that the students fail to complete competition within four hours due to more complex real estate development program. In the beginning of the skill competition, in the planning skill training system of the real estate development projects, the public transfer announcement of the land use right and all required basic data, including the basic data for risk analysis are released to all training students. To increase the interest of the skill competition, at the end of the skill competition, the rank of the students who participate in the competition is arranged according to the following criteria: 
(1) Successively arrange the rank of the students who participate in the competition according to the level of the highest quotation in the transaction of the construction land use right determined by planning.

(2) Successively arrange the rank of those students according to the level of the sales revenue of the real estate development projects estimated by planning.

(3) Successively arrange the rank of those students according to the level of the total cost and expense of the real estate development projects estimated by planning.

(4) Successively arrange the rank of those students according to the profits of the real estate development projects estimated by planning.

(5) Successively arrange the rank of those students according to the total taxes of the real estate development projects estimated by planning.

(6) Successively arrange the rank of those students according to the time to complete the planning.

\section{DESIGN OF TRAINING SYSTEM}

The publicized period of the public transfer announcement of the land use right is generally 10 days to 20 days based on the land area, and the end time of publicity is also the deadline of the potential transferee of the land use right submitting an application for participating in the public transfer traction and delivering the training deposit ${ }^{[3]}$.

After becoming aware of the public transfer announcement of the land use right, if there is an intention to transfer the land use right for the real estate development, the - developers must complete the planning of development projects before the end time of the publicized period, and decide whether to participate in the public transfer transaction of the land use right, in order to submit the application for participating in the public transfer transaction of the land use right and deliver the trading deposit.

With the popularization of the information technology, the real estate developers have already adopted the computers and information technology for the planning of the real estate development projects, in order to accommodate the requirements of rapid completion of planning the real estate development projects within the publicized period. Some of planning software of the real estate development projects adopted by the real estate developers are developed by the real estate developers, and some of commercial software are purchased from the software vendors. Therefore, the colleges and universities must adopt the information technology to establish the planning skill training system of the real estate development projects, and carry out the planning skill training - for the students, rather than carrying out the planning skill training system by the paper-based mode or Excel spreadsheet on computer.

\subsection{Hardware design of skill training system}

The skill training of the real estate development projects in colleges and universities is different from that of planning of the real estate development projects by the real estate developers, which is carried out on a terminal computer by all students in a class or even in the same grade, so that the teachers can focus on the guidance. In order to meet the requirements of training for all students in a class or even in the same grade, there is a must to configure a server and a sufficient number of terminal computers, and form a local area network through connection with the network data switching exchanges. Windows SERVER 2008 operating system and PHPStudy operating platform are installed on the server, while Windows 8 operating system is installed on a terminal computer.

An ordinary computer can be as a server to train all students majored with the real estate operation and valuation in a class and a sufficient number of terminal computers can be configured according to the number of students in a class. CPU clock speed of the server is $3 \mathrm{GHz}$, configured with $4 \mathrm{G}$ memory, 2.5 -inch SSD128G solid state disk and 1000M adaptive network card. CPU clock speed of the terminal computer is $2 \mathrm{GHz}$, configured with $2 \mathrm{G}$ memory, 3.5-inch HDD hard disk and $1000 \mathrm{M}$ adaptive network card. The teachers directly use it as a server computer for skill training guidance, skill training management and skill training software maintenance.

To train all students majored with the real estate operation and valuation in a class, it is not easy to use the ordinary computer as a server, but it is better to use a rack-mounted server. CPU clock speed of the server is $4 \mathrm{GHz}$, configured with $8 \mathrm{G}$ memory, 3.5-inch SAS hard disk and two $1000 \mathrm{M}$ network cards. To facilitate the teachers to do skill training guidance, skill training management and skill training software maintenance, it is necessary to fix a terminal computer for exclusive use by the teachers.

\subsection{Software design of skill training system}

The software vendors plan the commercial software of the real estate development projects sold to the real estate developers, which is free of auxiliary functions of the training management. The price is too expensive for the colleges and universities, so it is not appropriate for the colleges and universities to buy commercial software for training students. However, the colleges and universities possess the professional teachers of the real estate development, professional teachers of the information technology and professional engineers of the information technology, who entirely have the ability and should develop the planning skill training system software of the real estate development projects. 


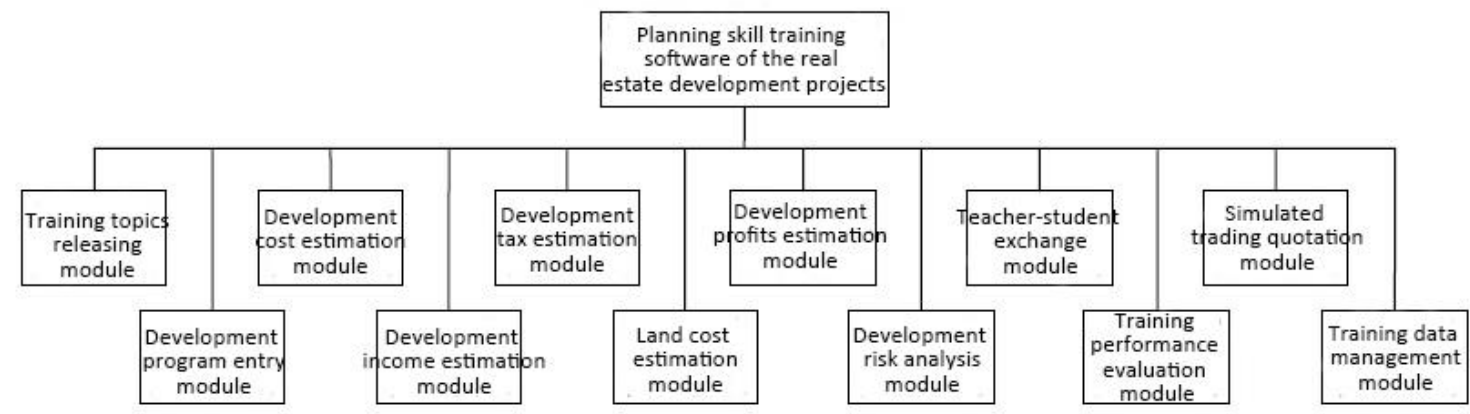

Figure 2. Planning skill training software module of the real estate development projects

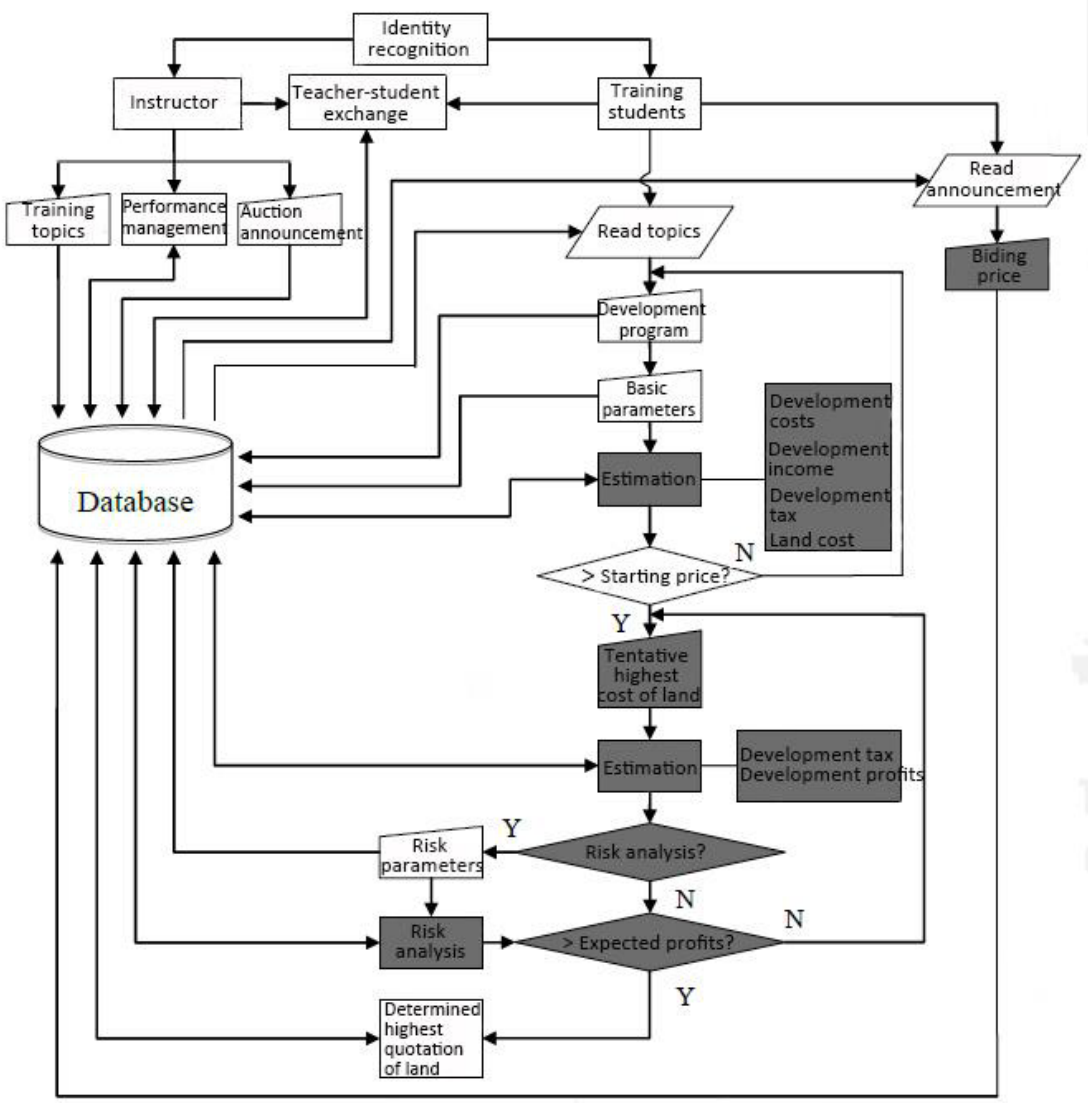

Figure 3. Flow chart of planning skill training system of real estate development projects

The planning skill training software of the real estate development projects is prepared by the use of NetBeans development tools, and installed on the server. While training, the students visit the server from their respective terminal computers, start the planning software of the real estate development projects and complete training on their respective terminal computers according to the training procedures.

The planning skill training software of the real estate development projects adopts the modular structure. All of 12 function modules are shown in Figure 2.

The planning skill training software of the real estate development projects possesses all functions of simulating the planning of the real estate development projects and auxiliary functions of the skill training management, which can support the designed primary training method, intermediate training method, advanced training method and skill competition method.

Figure 3 shows a complete process of the planning skill training of the real estate development projects by the use of the planning skill training software of the real estate development projects.

\section{CONCLUSION}

According to the in-depth investigation of the real estate developers, the development idea on the planning skill training system of the real estate development projects is formed after adequate research and 
discussion. We believe that the design of training content has an adequate basis, the design of training method is thorough and feasible, and the design of training system has a reasonable technology. The planning skill training system of the real estate development projects developed by this idea is used for skill training for the students majored with the real estate operation and valuation in colleges and universities, which can improve the efficiency and quality of skill training, successfully achieve the objective of training the students to firmly grasp the planning skills of the real estate development projects, and greatly enhance the competitiveness of employment after graduation.

\section{REFERENCES}

[1] Ministry of Land and Resources of People's Republic of China. Order No. 39 of Ministry of Land and Resources of People's Republic of China--Provision of State-owned Construction Land Use Right Transferred by Bid and Auction Listing [Z]. 2007-09-28 / 2015-10-21.

[2] Chongqing Municipal People's Government. Transfer management implementation approach of the state-owned construction land use right in Chongqing [Z]. 2008-11-19/2015-10-21.

[3] Chongqing Municipal Land Resources and Housing Management Bureau. Transaction rules of the state-owned construction land use right in Chongqing [S]. 2009-11-01/2015-10-21 